\title{
Evaluation of individual health literacy among inpatients of different types of hospitals in Istanbul
}

\author{
Hüseyin KÜÇÜKALI $\dot{I}^{1}$ (D) Ömer ATAÇ ${ }^{1} \mathbb{D}$, Orhan ÖZER² ${ }^{\mathbb{D}}$, Osman HAYRAN ${ }^{1}$ (D) \\ 1 Department of Public Health, School of Medicine, Istanbul Medipol University, Istanbul, Turkey. \\ 2 Graduate School of Health Sciences, Istanbul Medipol University, Istanbul, Turkey. \\ Corresponding Author: Hüseyin KÜÇÜKALİ \\ E-mail: hkucukali@medipol.edu.tr
}

Submitted: $06.01 .2020 \quad$ Accepted: 27.03 .2020

\begin{abstract}
Objective: The objective of our study is to evaluate the individual health literacy level among patients who received health services from different types of hospitals in Istanbul.

Materials and Methods: This cross-sectional study was conducted among inpatients of a public, private and university hospital in Istanbul. Data were collected by the application of a questionnaire to 1500 adult inpatients who were discharged between February-July 2017. The study questionnaire included questions to determine the health literacy competency and sociodemographic characteristics of patients. Rapid Estimate of Adult Literacy in Medicine (REALM) scale was used to measure the health literacy level.

Results: The mean REALM score was higher among females than males $(\mathrm{p}<0.013)$. Health literacy mean score was lowest among public hospital inpatients and highest among university hospital inpatients $(\mathrm{p}<0.001)$. Primary-school graduate patients had significantly lower scores $(\mathrm{p}<0.001)$ than the other groups. The findings of the REALM test were in agreement with the health literacy competencies.

Conclusion: Males, patients older than 35 years old, primary-school graduates, and public hospital inpatients had lower levels of health literacy.

Keywords: Health Literacy, Health Services, Patients, Inpatients
\end{abstract}

\section{INTRODUCTION}

Health literacy is defined as "people's knowledge, motivation and competences to access, understand, appraise, and apply health information in order to make judgments and take decisions in everyday life concerning healthcare, disease prevention and health promotion to maintain or improve quality of life during the life course" [1]. It is a life-long activity that needs to be continuously improved.

Health literacy has become an important concept in the healthcare sector because it increases the effectiveness and efficacy of the services and reduces health expenditures. Studies show that the success of the health services and achievement of desired outcomes are related to the health literacy level of the service-taker [2 - 4].

Education, socioeconomic status, cultural, social and environmental factors affect the health literacy level and therefore, health outcomes and costs are also affected $[5,6]$. Today, it is easy to access the health information. Beside the healthcare providers such as physicians, nurses, pharmacists, the information can be obtained from media, internet and community advice. While facing this variety of information, the ability to understand is dependent on the health literacy level of the person [7].

In a report of Social Determinants Commission of the World Health Organization, health literacy has been recognized as a critical determinant for mitigating health inequalities. The report emphasizes the value of improving health literacy [8].

Health literacy has begun to gain attention by the end of the 20th century in the United States (US) and after in the European Union (EU) [9]. Multiple studies from the US demonstrated the effect of health literacy in quality, cost, organization, and management of the health services. In a study conducted in eight EU countries, it has been shown that the health literacy level of the European people was inadequate. Recognizing the importance of health literacy, the EU has begun to implement various policies on this issue. Researches show that 29-62\% of the population in the EU and $26 \%$ in the US do not have a sufficient level of health literacy [10]. 
According to a report published by UNESCO in 2009, 776 million adults were not health literate at primary level [11]. It is known that insufficient health literacy causes increase in the rate of hospitalization and amount of the health expenditures, gives rise to accessibility problems in health services, the use of the wrong medicines and the deterioration of health status [5].

In Turkey, a study conducted by Health and Social Service Workers' Union, showed that $64.6 \%$ of the population had inadequate or problematic health literacy. The results of this study revealed that approximately $12.5 \%$ of health expenditure in a year was spent due to insufficient or problematic health literacy [5].

This study aims to measure individual health literacy levels of patients who received healthcare at different types of hospitals in Istanbul, Turkey.

\section{MATERIALS and METHODS}

This is a cross-sectional study conducted in three hospitals a public hospital, private hospital and university hospital in Istanbul. Each of these was accredited hospitals in terms of their quality. Individual health literacy data were collected from inpatients who were over 15 years old, hospitalized in a period between February and July 2017 and accepted to participate in the study. The sample size for each hospital was calculated separately. To estimate a proportion for the unlimited population at $95 \%$ confidence level with 5\% sampling error and anticipated $50 \%$ proportion, 384 people for each hospital was found to be required as a sample. While taking into account the losses that may occur during the data collection, it is planned to collect data from 500 people for each hospital, 1,500 people in total.

Data were collected by a questionnaire during face-to-face interviews. The questionnaire included questions about sociodemographic characteristics, health literacy level and health literacy competencies of the study group.

Rapid Estimate of Adult Literacy in Medicine (REALM) scale was used for measuring the health literacy level. REALM test has been developed by Davis et al. [12]. It is based on people's ability to read, pronounce and understand 66 medical words. Total application time of the test lasts for 3-5 minutes while the total evaluation score is interpreted as health literacy level, such as 0-18 points for a 3rd grader or lower, 19-44 points for 4-6th grader, 45-60 points for 7-8th grader and 61-66 points indicate the high schooler level of health literacy. The evaluation can be made by a categorical grouping of the points taken, as well as by comparing the mean scores of the different groups. Turkish version of the REALM was prepared and found to be valid and reliable by Özdemir et al. [13].

Beside the REALM test, participants were also asked if they have these three health literacy competencies: reading the medical brochures, understanding the medical documents and filling the forms by themselves in health institutions.
These competencies will be mentioned as reading, understanding and filling competencies for the convenience hereafter.

\section{Statistical Analysis}

Data analysis and statistical evaluation of the results was made via SPSS 23.0 software. Descriptive statistics such as mean, standard deviation, percentage and significance tests were used to compare various groups of people. According to the type of data and number of groups, comparisons between groups were evaluated by significance tests such as the t-test, ANOVA, Chisquare test and 0.05 was considered as the significance threshold for $\mathrm{p}$-value. Post-hoc analysis of significant ANOVA results was done by Tukey test. Multiple linear regression analysis was used to control the effect of confounding factors.

Ethical approval was obtained from the Medipol University Non-Invasive Clinical Research Ethics Committee on October 9th, 2015. Official permissions were obtained from the hospital administrations before the study was conducted.

\section{RESULTS}

Table I presents the comparison of mean REALM scores and frequencies of reading, understanding and filling competencies of patients by gender groups. A statistically significant difference was found between the mean health literacy scores of males and females $(t=2.500, p=0.013)$. Females' mean health literacy score was higher than males'. Reading $(\mathrm{p}=0.373)$ and filling $(\mathrm{p}=0.174)$ competencies did not show a significant difference between gender. However, there was a statistically significant difference between the two groups in terms of understanding competency $(\mathrm{p}=0.019)$.

Table I. Mean REALM scores and reading, understanding and filling competencies of patients by gender groups.

\begin{tabular}{|c|c|c|c|c|c|c|c|}
\hline & REALM Score & \multicolumn{2}{|c|}{$\begin{array}{c}\text { Filling } \\
\text { forms }\end{array}$} & \multicolumn{2}{|c|}{$\begin{array}{c}\text { Understanding } \\
\text { documents }\end{array}$} & \multicolumn{2}{|c|}{$\begin{array}{c}\text { Reading } \\
\text { brochures }\end{array}$} \\
\hline Gender & Mean \pm SD & $\mathbf{n}$ & $\%$ & $\mathbf{n}$ & $\%$ & $\mathbf{n}$ & $\%$ \\
\hline $\begin{array}{c}\text { Male } \\
(\mathrm{n}=675)\end{array}$ & $55.36 \pm 9.52$ & 496 & 80.4 & 454 & 69.8 & 566 & 86.5 \\
\hline $\begin{array}{c}\text { Female } \\
(\mathrm{n}=764)\end{array}$ & $56.56 \pm 8.79$ & 556 & 78.4 & 567 & 76.2 & 655 & 87.8 \\
\hline $\begin{array}{c}\text { Total } \\
(\mathrm{n}=1439)\end{array}$ & $56.00 \pm 9.16$ & 1052 & 79.3 & 1021 & 76.9 & 1221 & 92.1 \\
\hline & $\mathrm{t}=2.500$, & \multicolumn{2}{|c|}{$\chi^{2}=3.498}$, & \multicolumn{2}{|c|}{$\chi 2=7.891}$, & \multicolumn{2}{c|}{$\begin{array}{c}2=1.972, \\
\mathrm{p}=0.373\end{array}$} \\
\hline
\end{tabular}

Rapid Estimate of Adult Literacy in Medicine (REALM)

Table II presents the comparison of mean REALM scores and frequencies of reading, understanding and filling competencies of patients by age groups. 
There was no statistically significant difference between the mean health literacy scores of different age groups $(\mathrm{p}=0.087)$. However, the percentage of the people with reading, understanding and filling competency decreased as age increased and these differences were statistically significant ( $p<0.001$ in each). This difference was mainly due to high levels of health literacy in younger (25-34 and 15-24) age groups.

Table II. Mean REALM scores and reading, understanding and filling competencies of patients by age groups

\begin{tabular}{|l|c|c|c|c|c|c|c|}
\hline & REALM Score & \multicolumn{2}{|c|}{ Filling forms } & \multicolumn{2}{|c|}{$\begin{array}{c}\text { Understanding } \\
\text { documents }\end{array}$} & \multicolumn{2}{|c|}{$\begin{array}{c}\text { Reading } \\
\text { brochures }\end{array}$} \\
\hline $\begin{array}{l}\text { Age } \\
\text { Group }\end{array}$ & Mean \pm SD & $\mathbf{n}$ & $\%$ & $\mathbf{n}$ & $\%$ & $\mathbf{n}$ & $\%$ \\
\hline $\begin{array}{l}15-24 \\
(\mathrm{n}=205)\end{array}$ & $55.04 \pm 8.81$ & 156 & 80.0 & 157 & 78.5 & 182 & 91.0 \\
\hline $\begin{array}{l}25-34 \\
(\mathrm{n}=485)\end{array}$ & $56.51 \pm 8.79$ & 390 & 85.9 & 371 & 77.8 & 436 & 91.4 \\
\hline $\begin{array}{l}35-44 \\
(\mathrm{n}=345)\end{array}$ & $56.09 \pm 8.79$ & 253 & 80.3 & 244 & 72.6 & 295 & 87.3 \\
\hline $\begin{array}{l}45-54 \\
(\mathrm{n}=200)\end{array}$ & $55.07 \pm 10.95$ & 142 & 78.5 & 125 & 66.5 & 158 & 82.7 \\
\hline $\begin{array}{l}55-64 \\
(\mathrm{n}=119)\end{array}$ & $54.79 \pm 10.29$ & 71 & 67.0 & 78 & 67.2 & 90 & 77.6 \\
\hline $\begin{array}{l}>64 \\
(\mathrm{n}=94)\end{array}$ & $57.32 \pm 8.22$ & 42 & 51.9 & 47 & 57.3 & 63 & 75.0 \\
\hline $\begin{array}{l}\text { Total } \\
(\mathrm{n}=1448)\end{array}$ & $55.92 \pm 9.23$ & 1054 & 79.1 & 1022 & 73.1 & 1224 & 87.1 \\
\hline $\begin{array}{l}\mathrm{t}=1.925, \\
\mathrm{p}=0.087\end{array}$ & $\begin{array}{l}\chi 2=69.634, \\
\mathrm{p}<0.001\end{array}$ & $\begin{array}{l}\chi 2=36.066, \\
\mathrm{p}<0.001\end{array}$ & $\begin{array}{l}\chi 2=41.310, \\
\mathrm{p}<0.001\end{array}$ \\
\hline
\end{tabular}

Rapid Estimate of Adult Literacy in Medicine (REALM)

Table III presents the comparison of mean REALM scores and frequencies of reading, understanding and filling competencies of patients by the type of hospital. The mean REALM scores of the patients differed significantly by hospital types $(\mathrm{p}<0.001)$. The difference was caused by low health literacy level of the patients in the public hospital and high health literacy level of the patients in the university hospital. A statistically significant difference was found in filling competency by the hospital type $(\mathrm{p}<0.05)$. Because the percentage of patients who can filled the forms themselves was significantly lower in the private hospital than others. There was also a significant difference in understanding competency between the groups $(\mathrm{p}<0.001)$. It was observed that this difference was mainly due to the group of the university hospital. However, significant differences were found between each group. There was no statistically significant difference in reading competency between patients of different hospital types $(\mathrm{p}=0.090)$.
Table III. Mean REALM scores and reading, understanding and filling competencies of patients by type of hospital

\begin{tabular}{|l|c|c|c|c|c|c|c|}
\hline & REALM Score & \multicolumn{2}{|c|}{ Filling forms } & \multicolumn{2}{|c|}{$\begin{array}{c}\text { Understanding } \\
\text { documents }\end{array}$} & \multicolumn{2}{|c|}{$\begin{array}{c}\text { Reading } \\
\text { brochures }\end{array}$} \\
\hline $\begin{array}{l}\text { Hospital } \\
\text { Type }\end{array}$ & Mean \pm SD & $\mathbf{n}$ & $\%$ & $\mathbf{n}$ & $\%$ & $\mathbf{n}$ & $\%$ \\
\hline $\begin{array}{l}\text { University } \\
(\mathrm{n}=491)\end{array}$ & $58.34 \pm 6.95$ & 374 & 80.4 & 385 & 80.5 & 438 & 89.4 \\
\hline $\begin{array}{l}\text { Private } \\
(\mathrm{n}=486)\end{array}$ & $56.79 \pm 8.99$ & 337 & 77.5 & 322 & 74.2 & 391 & 87.5 \\
\hline $\begin{array}{l}\text { Public } \\
(\mathrm{n}=482)\end{array}$ & $52.58 \pm 10.55$ & 351 & 79.4 & 313 & 68.5 & 403 & 84.1 \\
\hline $\begin{array}{l}\text { Total } \\
(\mathrm{n}=1459)\end{array}$ & $55.92 \pm 9.26$ & 1062 & 79.1 & 1020 & 74.5 & 1232 & 87.0 \\
\hline & $\begin{array}{l}\mathrm{t}=53.847, \\
\mathrm{p}<0.001\end{array}$ & $\begin{array}{r}\chi 2 \\
\mathrm{p}=12.937,\end{array}$ & \multicolumn{2}{|c|}{$\chi 2=18.012$} \\
$\mathrm{p}<0.001$ & $\begin{array}{c}\chi 2=8.048, \\
\mathrm{p}=0.090\end{array}$ \\
\hline
\end{tabular}

Rapid Estimate of Adult Literacy in Medicine (REALM)

Table IV presents the comparison of mean REALM scores and frequencies of reading, understanding and filling competencies of patients by their educational level. Mean REALM scores showed a significant difference by education level $(\mathrm{p}<0.001)$. The low mean score of the "primary school" group and the high mean scores of "middle-high school" and "university" groups caused this difference. Statistically significant differences were found in filling competency, understanding competency and reading competency between the educational levels $(p<0.001$ in each). Post-hoc analysis revealed that differences between each educational level were significant for each competency. As the educational level advanced, the percentages of all competencies increased. For reading competency, it was understood that this difference was primarily due to "primary school" level.

Table IV. Mean REALM scores and reading, understanding and filling competencies of patients by level of educational

\begin{tabular}{|l|c|c|c|c|c|c|c|}
\hline & REALM Score & \multicolumn{2}{|c|}{ Filling forms } & \multicolumn{2}{|c|}{$\begin{array}{c}\text { Understanding } \\
\text { documents }\end{array}$} & \multicolumn{2}{|c|}{$\begin{array}{c}\text { Reading } \\
\text { brochures }\end{array}$} \\
\hline $\begin{array}{l}\text { Educational } \\
\text { Level }\end{array}$ & Mean \pm SD & $\mathbf{n}$ & $\%$ & $\mathbf{n}$ & $\%$ & $\mathbf{n}$ & $\%$ \\
\hline $\begin{array}{l}\text { Primary } \\
\text { School } \\
(\mathrm{n}=341)\end{array}$ & $51.39 \pm 10.92$ & 185 & 61.3 & 168 & 52.3 & 239 & 73.8 \\
\hline $\begin{array}{l}\text { High School } \\
(\mathrm{n}=676)\end{array}$ & $55.75 \pm 8.80$ & 503 & 80.9 & 491 & 74.8 & 590 & 89.4 \\
\hline $\begin{array}{l}\text { University } \\
(\mathrm{n}=418)\end{array}$ & $59.83 \pm 6.52$ & 363 & 91.2 & 356 & 86.0 & 391 & 94.7 \\
\hline $\begin{array}{l}\text { Total } \\
(\mathrm{n}=1435)\end{array}$ & $55.90 \pm 9.30$ & 1051 & 79.5 & 1015 & 73.0 & 1220 & 87.3 \\
\hline & $\begin{array}{c}\mathrm{t}=86.842, \\
\mathrm{p}<0.001\end{array}$ & $\begin{array}{c}\chi 2=98.417, \\
\mathrm{p}<0.001\end{array}$ & \multicolumn{2}{|c|}{$\chi 2=107.628}$, & \multicolumn{2}{|c|}{$\mathrm{p}<0.001$} & $\begin{array}{c}2=80.438, \\
\mathrm{p}<0.001\end{array}$ \\
\hline
\end{tabular}

Rapid Estimate of Adult Literacy in Medicine (REALM) 
Table $\mathrm{V}$ presents the comparison of mean REALM scores and frequencies of reading, understanding and filling competencies of patients by their insurance type. There was a significant difference between the groups in mean REALM scores $(\mathrm{p}<0.001)$. There was also a significant difference between groups in the percentage of filling competency. This was caused by the differences between Social Security Insurance (SSI) - Working Plan and Private Insurance groups from other groups. There was a significant difference between the groups in the percentage of understanding competency $(\mathrm{p}<0.05)$. High percentages of understanding competency in SSI - Working Plan and Private Insurance groups were responsible for this difference. There was a statistically significant difference between the groups in the percentage of reading competency $(\mathrm{p}<0.001)$ and this difference was primarily due to the high percentage of reading competency of SSI - Working Plan group than others.

Table V. Mean REALM scores and reading, understanding and filling competencies of patients by insurance types

\begin{tabular}{|c|c|c|c|c|c|c|c|}
\hline & $\begin{array}{c}\text { REALM } \\
\text { Score }\end{array}$ & \multicolumn{2}{|c|}{ Filling forms } & \multicolumn{2}{|c|}{$\begin{array}{c}\text { Understanding } \\
\text { documents }\end{array}$} & \multicolumn{2}{|c|}{$\begin{array}{c}\text { Reading } \\
\text { brochures }\end{array}$} \\
\hline $\begin{array}{c}\text { Insurance } \\
\text { Type }\end{array}$ & Mean \pm SD & $\mathbf{n}$ & $\%$ & $\mathbf{n}$ & $\%$ & $\mathbf{n}$ & $\%$ \\
\hline $\begin{array}{c}\text { SSI } \\
\text { Working } \\
(\mathrm{n}=746)\end{array}$ & $56.11 \pm 8.92$ & 575 & 83.7 & 545 & 75.0 & 662 & 90.7 \\
\hline $\begin{array}{c}\text { SSI Retired } \\
(\mathrm{n}=228)\end{array}$ & $56.90 \pm 8.60$ & 137 & 67.8 & 145 & 67.8 & 179 & 82.9 \\
\hline $\begin{array}{c}\text { Private } \\
(\mathrm{n}=193)\end{array}$ & $57.22 \pm 10.00$ & 146 & 83.4 & 142 & 78.5 & 156 & 85.7 \\
\hline $\begin{array}{c}\text { Other } \\
(\mathrm{n}=257)\end{array}$ & $53.61 \pm 9.74$ & 179 & 73.1 & 172 & 67.7 & 209 & 82.3 \\
\hline $\begin{array}{c}\text { Total } \\
(\mathrm{n}=1424)\end{array}$ & $55.93 \pm 9.24$ & 1037 & 79.2 & 1004 & 73.0 & 1206 & 87.3 \\
\hline & $\mathrm{t}=7.687$, & \multicolumn{2}{|c|}{$\chi 2=35.570}$, & \multicolumn{2}{|c|}{$\chi 2=17.409}$, & \multicolumn{2}{|c|}{$\chi^{2}=21.091}$, \\
$\mathrm{p}<0.001$ & $\mathrm{p}<0.001$ & $\mathrm{p}=0.008$ & $\mathrm{p}=0.002$ \\
\hline
\end{tabular}

Rapid Estimate of Adult Literacy in Medicine (REALM), Social Security Insurance (SSI)

Table VI presents the comparison of mean REALM scores and distribution of reading, understanding and filling competencies of patients by their occupational categories. Mean REALM scores showed a statistically significant difference $(\mathrm{p}<0.001)$. Health literacy scores of health professionals and civil servants were significantly high and the score of housewives group was significantly low. While analyzing the reading, understanding and filling competencies, unemployed and retired groups were combined due to their low observed values.
Also, the health professionals group was excluded from the analysis due to null values in two cells of the analysis table. It was found that the patients' filling competencies differed significantly by their profession $(\mathrm{p}<0.001)$. It was seen that this difference was primarily due to the housewife group. Percentage of housewives who filled the forms on their own was significantly lower than other groups. The percentages of patients with understanding competency showed a significant difference by the occupational groups $(\mathrm{p}<0.001)$. It was observed that this difference was due to retired and self-employed groups. There was also a significant difference $(\mathrm{p}=0.002)$ between the reading competency by occupational groups because of the high percentage in the public servants group.

Table VI. Mean REALM scores and reading, understanding and filling competencies of patients by their occupational categories

\begin{tabular}{|c|c|c|c|c|c|c|c|}
\hline & $\begin{array}{c}\text { REALM } \\
\text { Score }\end{array}$ & \multicolumn{2}{|c|}{$\begin{array}{c}\text { Filling } \\
\text { forms }\end{array}$} & \multicolumn{2}{c|}{$\begin{array}{c}\text { Understanding } \\
\text { documents }\end{array}$} & \multicolumn{2}{|c|}{$\begin{array}{c}\text { Reading } \\
\text { brochures }\end{array}$} \\
\hline Occupation & Mean \pm SD & $\mathbf{n}$ & $\%$ & $\mathbf{n}$ & $\%$ & $\mathbf{n}$ & $\%$ \\
\hline $\begin{array}{c}\text { Student } \\
(\mathrm{n}=93)\end{array}$ & $55.86 \pm 7.44$ & 78 & 86.7 & 77 & 83.7 & 85 & 92.4 \\
\hline $\begin{array}{c}\text { Housewife } \\
(\mathrm{n}=416)\end{array}$ & $54.58 \pm 9.57$ & 274 & 72.5 & 289 & 71.5 & 341 & 84.0 \\
\hline $\begin{array}{c}\text { Self- } \\
\text { employed } \\
(\mathrm{n}=285)\end{array}$ & $54.85 \pm 10.67$ & 214 & 80.8 & 188 & 67.9 & 244 & 87.8 \\
\hline $\begin{array}{c}\text { Worker } \\
(\mathrm{n}=380)\end{array}$ & $56.33 \pm 8.66$ & 277 & 80.1 & 270 & 73.8 & 314 & 85.6 \\
\hline $\begin{array}{c}\text { Public } \\
\text { Servant } \\
(\mathrm{n}=115)\end{array}$ & $60.12 \pm 4.91$ & 103 & 92.0 & 94 & 83.2 & 110 & 97.3 \\
\hline $\begin{array}{c}\text { Health } \\
\text { Professional } \\
(\mathrm{n}=36)\end{array}$ & $62.76 \pm 4.17$ & 35 & 100.0 & 31 & 86.1 & 36 & 100.0 \\
\hline $\begin{array}{c}\text { Unemployed } \\
\text { or Retired } \\
(\mathrm{n}=95)\end{array}$ & $55.40 \pm 9.70$ & 59 & 69.4 & 55 & 61.1 & 74 & 81.3 \\
\hline $\begin{array}{c}\text { Total } \\
(\mathrm{n}=1420)\end{array}$ & $55.90 \pm 9.23$ & 1040 & 79.3 & 1004 & 72.9 & 1204 & 87.1 \\
\hline $\begin{array}{c}\mathrm{t}=8.719, \\
\mathrm{p}<0.001\end{array}$ & $\chi 2=37.220$, & $\mathrm{p}<0.001$ & $\mathrm{p}<0.001$ & $\chi 2=21.091$, \\
\hline
\end{tabular}

Rapid Estimate of Adult Literacy in Medicine (REALM)

Multiple linear regression analysis results are presented in Table VII. REALM scores of females, individuals who attended university hospitals and university graduates were significantly higher than the other groups. REALM scores significantly increased by age. Insurance type and occupation did not seem to be significant predictors of health literacy. 
Table VII. Linear regression results: factors associated with individual health literacy

\begin{tabular}{|c|c|c|c|c|c|}
\hline & B & SE & b & $\mathbf{t}$ & p \\
\hline Constant & 43.727 & 1.827 & & 23.937 & $<0.001$ \\
\hline Independent variables & & & & & \\
\hline $\begin{array}{l}\text { Gender } \\
\text { 0: Male 1: Female }\end{array}$ & 1.495 & 0.482 & 0.079 & 3.102 & $=0.002$ \\
\hline Age & 0.065 & 0.18 & 0.100 & 3.554 & $<0.001$ \\
\hline $\begin{array}{l}\text { Hospital type } \\
\text { 1: University 2: Private 3: } \\
\text { Public }\end{array}$ & -2.150 & 0.288 & -0.190 & -7.467 & $<0.001$ \\
\hline $\begin{array}{l}\text { Education level } \\
\text { 1: Primary 2: Secondary-High } \\
\text { 3: University }\end{array}$ & 3.706 & 0.314 & 0.329 & 11.809 & $<0.001$ \\
\hline $\begin{array}{l}\text { Insurance type } \\
\text { 1: SSI Working 2: SSI Retired } \\
\text { 3: Private 4: Other }\end{array}$ & -0.199 & 0.149 & -0.033 & -1.341 & $=0.180$ \\
\hline Occupation & 0.198 & 0.157 & 0.036 & 1.261 & $=0.207$ \\
\hline
\end{tabular}

The unstandardized beta $(B)$, the standard error for the unstandardized beta (SE $\mathrm{B})$, the standardized beta $(\beta)$, the $t$ test statistic $(\mathrm{t})$, and the probability value $(\mathrm{p})$, Social Security Insurance (SSI)

\section{DISCUSSION}

The mean REALM score of the study group was $56.0 \pm 9.16$. In a similar study conducted by Özdoğan, the mean was found as $55.8 \pm 11.2$ which was similar to ours' [14]. In comparison between genders, females' mean health literacy score (56.56 $\pm 8.79)$ was significantly higher than those of males (55.36 \pm 9.52 ) in our study. When genders were compared in terms of the competencies, females were found to understand the documents given in healthcare institutions better than males. While, in a similar study, it was found that females undestood such documents less than males [10]. However, it may be due to lower general literacy among females as it was mentioned in that study. There was no statistically significant difference in the competency of filling the forms between genders. Both groups often filled the forms themselves. According to Özdoğan's research, $45 \%$ of the patients answered as "I always read-and-fill myself" and 54\% of the participants stated that they ask other people to read-and-fill the given forms [14]. In our study, $79.3 \%$ of the patients said that they always filled the given forms themselves. There was no significant difference between the gender groups in the competency of reading the brochures. Aslantekin also could not find any significant relationship between gender and competency of reading the written documents such as scientific publications about their diseases [10].

When individual health literacy scores of patients were compared among age groups, no significant difference was observed. However, the percentage of people who filled the forms on their own, understood the texts written in documents and read the brochures, decreased as the age increased. These percentages decreased in the age group who were older than 25-34 years. Aslantekin's research could not find any statistical significance in the relationship between the age variable and competency of understanding the written documentation about diseases, such as informed consent forms [10]. This may be because our study sample was larger than Aslantekin's.

There was a significant difference between health literacy scores by the hospital type. Mean health literacy score was low in the public hospital and high in the university hospital. In a similar study conducted by Uğurlu, the health literacy scores of the patients who admitted to the public hospital were significantly lower than the university hospital patients [15]. When they investigated reading, understanding and filling competencies, they found that the percentage of competency among university hospital patients was higher than the percentages of other hospital types. Patients who received healthcare from the university hospital might have more contact with health professionals and information previously or might have higher awareness because of their presumably more complex health problems. But, further studies are required to determine the cause of this difference.

When individual health literacy scores of patients were compared between educational levels, the mean score increased as the educational level increased. A similar result was found in the study of Çopurlar [16]. Likewise, the percentages of people with reading, understanding and filling competencies increased with the educational level. Aslantekin also found a significant relationship between the understanding of written documents (such as informed consent forms) and educational background. $20 \%$ of the literate level people stated that they understood the documents, while $86.4 \%$ of participants were not a graduate of a university [10].

Some differences were observed in the individual health literacy status between groups of different health insurance types and occupational categories in univariate analyses but multiple regression analysis revealed that these differences were not statistically significant.

Patients' individual health literacy scores which were measured via the REALM scale and the reading, understanding and filling competencies demonstrated similar results when investigated under different classifications like age, hospital type, education, and occupation. These findings indicated that the REALM alone might be sufficient to measure health literacy. According to our study findings patients older than 35 years, primary school level education, unemployed or retired, receiving health services 
from the public hospital seemed to be less health literate. Actions should be taken for these groups to increase the level of health literacy.

Since the data of this study were collected from the limited number of hospitals in Istanbul, the results could not be generalized to any population.

\section{Compliance with Ethical Standards}

Ethical Approval: Ethical approval was obtained from the Medipol University Non-Invasive Clinical Research Ethics Committee on October 9th, 2015. Official permissions were obtained from the hospital administrations before the study was conducted.

Informed Consent: A written informed consent was obtained from each participant.

Funding: This study was funded by the Scientific and Technological Research Council of Turkey (TUBITAK) under 3001 Elementary R\&D Projects Support Program with project number of 215 S955.

Conflict of Interest: The authors declare that they have no conflict of interest.

Author Contributions: Concept and design: O.O., O.H., Supervision: O.H., Materials: O.O., O.H., Data collection: O.O., Analysis and interpretation: H.K., O.A., O.O., O.H., Literature search: H.K., O.A., O.O., Writing the article: H.K., O.A., O.O., O.H., Critical review: O.H., Final approval: H.K., O.A., O.O., O.H.

\section{REFERENCES}

[1] Sorensen K, Van den Broucke S, Fullam J, et al. Health literacy and public health: a systematic review and integration of definitions and models. BMC Public Health 2012;12:80. doi:10.1186/1471-2458-12-80

[2] Aboumatar HJ, Carson KA, Beach MC, Roter DL, Cooper LA. The impact of health literacy on desire for participation in healthcare, medical visit communication, and patient reported outcomes among patients with hypertension. J Gen Intern Med 2013;28:1469-76. doi:10.1007/s11606.013.2466-5

[3] Callahan LF, Hawk V, Rudd R, et al. Adaptation of the health literacy universal precautions toolkit for rheumatology and cardiology - applications for pharmacy professionals to improve self-management and outcomes in patients with chronic disease. Res Social Adm Pharm 2013;9:597-608. doi:10.1016/j.sapharm.2013.04.016
[4] Kaphingst KA, Weaver NL, Wray RJ, Brown ML, Buskirk T, Kreuter MW. Effects of patient health literacy, patient engagement and a system level health Literacy attribute on patient-reported outcomes: A representative statewide survey. BMC Health Serv Res 2014;14:475. doi:10.1186/1472-696314-475

[5] Durusu Tanrıöver M, Yıldırım HH, Demiray Ready FN, Çakır B, Akalın HE. Türkiye sağlık okuryazarlığı araştırması. Ankara: Sağlık-Sen Yayınları, 2014.

[6] Yılmaz M, Tiryaki Z. Sağlık Okuryazarlığı Nedir? Nasıl Ölçülür? DEUHFED 2016;9:142-147.

[7] Üçpunar E. Yetişkinlerde işlevsel sağlık okuryazarlığı testinin uyarlama çalışması. Ankara Üniversitesi Sağlık Bilimleri Enstitüsü, Yüksek Lisans Tezi, Ankara, 2014.

[8] Yılmazel G, Çetinkaya F. Sağlık okuryazarlığının toplum sağlı̆̆ 1 açısından önemi. TAF Prev Med Bull 2016;15:69-74. doi:10.5455/pmb.1-144.887.0518

[9] HLS-EU Consortium. Comparative report on health literacy in eight EU member states. The European Health Literacy Project 2009-2012. Maastricht http://www.health-literacy.eu Access date: 15 December 2017.

[10] Aslantekin F. Yetişkinlerin sağlık okuryazarlık durumları ve etkileyen faktörler. Ankara Üniversitesi Eğitim Bilimleri Enstitüsü, Doktora Tezi, Ankara, 2011.

[11] Sezer A. Sağlık okuryazarlığının sağlıklı yaşam biçimi davranışları ile ilişkisi. Marmara Üniversitesi Sağlık Bilimleri Enstitüsü, Yüksek Lisans Tezi, İstanbul, 2012.

[12] Davis TC, Long SW, Jackson RH, et al. Rapid estimate of adult literacy in medicine: A shortened screening instrument. Fam Med 1993;25:391-5.

[13] Ozdemir H, Alper Z, Uncu Y, et al. Health literacy among adults: a study from Turkey. Health Educ Res 2010;25: 464-77. doi:10.1093/her/cyp068

[14] Özdoğan P, Radyoterapi alan hasta ve yakınlarının sağlık okuryazarlığı ve gereksinimlerine yönelik öğretim materyali geliştirilmesi. Başkent Üniversitesi Sağlık Bilimleri Enstitüsü, Yüksek Lisans Tezi, Ankara, 2014.

[15] Uğurlu Z, Sağlık Kurumlarına başvuran hastaların sağlık okuryazarlığının ve kullanılan eğitim materyallerinin sağlık okuryazarlığına uygunluğunun değerlendirilmesi. Başkent Üniversitesi Sağlık Bilimleri Enstitüsü, Doktora Tezi, Ankara, 2011.

[16] Çopurlar CZ. Kadınların sağlık okuryazarlık düzeyinin meme kanseri bilgi ve tarama davranışı ile ilişkisi. Dokuz Eylül Üniversitesi, Tıp Fakültesi, Aile Hekimliği Anabilim Dalı, Uzmanlık Tezi, İzmir, 2016. 